\title{
State of the Art of Job Satisfaction Measures: A Systematic Review
}

\author{
Gabriela Pereira Rangel Hora ${ }^{1, *}$ \\ Orcid.org/0000-0002-2990-4869 \\ Rodolfo Ribas Júnior ${ }^{1}$ \\ Orcid.org/0000-0001-6119-6754 \\ Marcos Aguiar de Souza ${ }^{1}$ \\ Orcid.org/0000-0001-66 09-8766
}

${ }^{1}$ Universidade Federal do Rio de Janeiro, Rio de Janeiro, RJ, Brasil

\begin{abstract}
Job satisfaction is a psychological variable that has been studied in contemporary organizational science due to its relation with a series of variables such as performance, turnover, organizational commitment and resilience. One problem found in the scientific literature is the lack of uniformity regarding the use of measures of job satisfaction. In order to identify the state of the art of instruments that evaluate work satisfaction worldwide, in Latin America and in Brazil, a systematic review on the Web of Knowledge, Scopus and SciELO bases has been conducted. The search generated a list of 357 articles that, after applying exclusion criteria, were reduced to 154 . Altogether 62 different scales were found in 42 different countries around the world. Regarding the overall results, two scales were identified as the most used in the international studies, as well as in relation to the studies carried out in Latin America. In Brazil, only one scale could be considered.
\end{abstract}

Keywords: Satisfaction, job, psychology, instruments, measure.

\section{Estado da Arte das Medidas em Satisfação no Trabalho: Uma Revisão Sistemática}

\section{Resumo}

Satisfação no trabalho é uma variável psicológica que vem sendo estudada na ciência organizacional contemporânea por sua relação com uma série de variáveis como performance, turnover, comprometimento organizacional e resiliência. Um problema encontrado na literatura científica é a ausência de uniformidade no uso de medidas que quantifiquem a satisfação laboral. Com o objetivo de identificar o estado da arte de instrumentos que avaliem a satisfação no trabalho no mundo, na América Latina e no Brasil, uma revisão sistemática nas bases Web of Knowledge, Scopus e SciELO foi conduzida. Os resultados geraram um montante de 357 artigos que, após aplicados critérios de exclusão, foram reduzidos a 154. Ao todo foram encontradas 62 escalas diferentes usadas em 42 países distintos em todo mundo.

Mailing address: Avenida Genaro de Carvalho, 1521, Apt. 101, Recreio do Bandeirantes, Rio de Janeiro, Brasil 22795-077. E-mail: gabrielahora@gmail.com 
Em relação aos resultados globais, duas escalas foram identificadas como as mais utilizadas nos estudos internacionais, bem como em relação aos estudos realizados na América Latina. Já no Brasil, apenas uma escala pode ser considerada.

Palavras-chave: Satisfação, trabalho, psicologia, instrumentos, medida.

\section{Estado del Arte de Medidas en Satisfacción Laboral: Una Revisión Sistemática}

\section{Resumen}

La satisfacción laboral es una dimensión psicológica que se ha estudiado en ciencias de la organización contemporánea gracias a su relación con: el rendimiento, el turnover, el compromiso organizacional y capacidad de recuperación. Un problema encontrado en la literatura científica es la falta de uniformidad en el uso de medidas que cuantifican satisfacción en el trabajo. Con la intención de identificar el estado de las herramientas de evaluación de la satisfacción en el trabajo en el mundo, en América Latina y Brasil, una revisión sistemática en las bases Web of Knowledge, Scopus y SciELO se llevó a cabo. Los resultados generaron un total de 357 artículos que después de aplicar los criterios de exclusión, se redujeron a 154. En total, se encontraron 62 diferentes escalas utilizadas en 42 países diferentes en todo el mundo. A respecto a los resultados generales, dos escalas fueron elegidos como la relación más utilizados, así como en América Latina. En Brasil, sólo una escala puede ser considerada.

Palabras clave: Satisfacción, trabajo, psicología, instrumentos, medida.

Job satisfaction can be understood as the extent to which a worker likes his or her work activity. This psychological valence has been historically understood in this way since its earliest studies in 1934 by Richard Uhrbrock. However, it was only in 1976 that Edwin Locke presented a satisfactory theoretical model that was used by the Psychology of Work and Organizations (PW\&O) as a reference in the studies on work activity satisfaction. The theory of job satisfaction suggests that being satisfied is essentially an attitude from which the workers' relationships with their work are formed (Locke, 1976). From the perspective of this theory, attitude has affect as its central dimension, it can be positive and negative, with the difference between these affects determining the level of satisfaction of an individual (Locke \& Latham, 2002). In other words, if the workers maintains more positive than negative affects, then they will have positive satisfaction and vice versa.

Van Saane, Sluiter, Verbeek, and FringsDresen (2003) argued that, in general, studies start from the hypothesis that job satisfaction would function as a sort of antidote capable of combating conditions that favor high turnover due to a small but significant negative correlation between job satisfaction and turnover. In addition, job satisfaction could also counter other negative influences in the work environment, such as occupational stress (van Saane et al., 2003).

A recent study showed that job satisfaction has a negative correlation with turnover and is a strong predictor of resignation and requests for changing the company (Mudor \& Tooksoon, 2011). Evidence also suggests that job satisfaction is a variable capable of predicting turnover more accurately than salary satisfaction (Singh \& Loncar, 2010). Alarcon and Edwards (2011) suggest that organizational commitment is closely linked to job satisfaction and turnover. The researchers conducted a study in which evidence indicated organizational impairment capable of predicting job satisfaction and job resignation rates (Alarcon \& Edwards, 2011).

Authors also suggest that satisfaction is associated with work performance and its mediators. More recent studies have shown that job satisfaction is positively correlated with organi- 
zational commitment, which in turn is a mediator of productivity (Van De Voorde, Paauwe, \& Van Veldhoven, 2012). Nyberg (2010), in his meta-analysis, sought to evaluate the relationship between job satisfaction and performance, presenting results that showed a significant correlation $(r=0.34)$ between these variables $(\mathrm{Ny}-$ berg, 2010). The theoretical model of Locke and Latham (2002) suggests that job satisfaction directly affects the willingness of the workers to commit to new challenges in their work environment. Locke (1976) gave the name of Motivation in the work to this conscious will to accomplish tasks healthily considered as challenges. This dimension seems to affect other mediating aspects of performance such as self-efficacy, commitment to the work and resilience. A metaanalysis performed to understand the mediators of job performance showed that individuals with high self-efficacy tended to set more ambitious goals, to be more committed to the work and to be more resilient to negative feedback from superiors when compared to individuals with low self-efficacy, which would positively affect the performance and job satisfaction of these individuals (Judge \& Bono, 2001).

Organizational commitment, or commitment to the job are empirically linked through a positive linear function with job satisfaction, that is, the greater the satisfaction, the greater the commitment to work. An empirical study conducted among civil servants in a Middle Eastern country showed that, despite cultural issues, workers with higher levels of satisfaction committed themselves more in a process of change in the organizational structure (Yousef, 2017). In the private sector, a study with 734 participants from a large Canadian company showed a positive correlation $(r=0.80)$ between organizational commitment and job satisfaction (Mathieu, Fabi, Lacoursière, \& Raymond, 2016).

Resilience in the face of negative feedback from a supervisor or superior is one of the psychological valences that has been studied due to it having a positive linear relationship with job satisfaction. There is evidence that positively links the ability to continue with the same level of performance after negative feedback, whether this is depreciation of the work or questioning the choice in a given task at work, to the individual's level of self-efficacy and job satisfaction (Chen, Lam, \& Zhong, 2007). On the other hand, it seems that this is a system of feedback between the variables, since there are results that suggest that higher levels of job satisfaction increase the worker's chance of being resilient and decreases the chance of a drop in performance (Abbas, Raja, Darr, \& Bouckenooghe, 2014).

In order to evaluate the relationship between job satisfaction and other organizational variables, PW\&O researchers use different instruments in their investigations. According to van Saane et al. (2003), studies that explore the aforementioned theme have been carried out with various types of measures (e.g., global or multidimensional instruments, instruments with single or multiple items, instruments created for workers in general or for only one category of worker, and qualitative interviews). However, studies indicating the state of the art in the investigation of job satisfaction in $\mathrm{PW} \& \mathrm{O}$ studies are rare. With the aim of reducing this gap in the scientific literature, the present work proposes to carry out a systematic review with three levels of inquiry: measures most used in Brazil, instruments used in Latin America and, finally, instruments used in the rest of the world. This review aimed to indicate which instruments are the most used and should therefore be favored in research in the area to allow comparisons between studies, cultures (International Test Commission [ITC], 2010) and reproducibility of results, something questioned to a great extent in Social Psychology (Van Bavel, Mende-Siedlecki, Brady, \& Reinero, 2016).

\section{Methods}

In order to identify the Job Satisfaction measuring instruments used worldwide, in Latin America and in Brazil and to try to answer the questions proposed in the present study, a systematic online review was carried out in the following platforms: SciELO, Web of knowledge and Scopus. Articles published between January 1995 and April 2015 were investigated. The re- 
view was limited to three languages of the main author: English, Spanish and Portuguese. The keywords were used in the study following the standards presented in Table 1, always using the "AND" Boolean operator.

The inclusion criteria of the articles for the present study considered 4 elements: (a) To have the words Job Satisfaction or their respective synonyms in the title of the publication and the term Instrument or its respective synonyms in the abstract, as described in Table 1; (b) to have been published in a peer review journal; (c) to have Job Satisfaction as the central theme or as a relevant measured variable; and (d) to be avail-

Table 1

Operationalization of the Search Terms

\begin{tabular}{lccccc}
\hline \multicolumn{2}{c}{ Scopus and Web of Knowledge } & \multicolumn{2}{c}{ SciELO - PTBR } & SciELO - ESP \\
\hline Job satisfaction & Instruments & $\begin{array}{c}\text { Satisfação } \\
\text { no Trabalho }\end{array}$ & Instrumentos & $\begin{array}{c}\text { Satisfacción } \\
\text { del trabajo }\end{array}$ & Instrumentos \\
Job satisfaction & Instrument(s) & $\begin{array}{c}\text { Satisfação } \\
\text { no Trabalho }\end{array}$ & Instrumento(s) & $\begin{array}{c}\text { Satisfacción } \\
\text { del trabajo }\end{array}$ & Instrumento(s) \\
Work satisfaction & Scale(s) & $\begin{array}{c}\text { Satisfação } \\
\text { no Emprego }\end{array}$ & Escala(s) & Satisfacción & Cuestionário(s) \\
& Questionnaire(s) & & & & \\
& Inventory(ies) & & & &
\end{tabular}

Note. All words were connected using the Boolean operators "AND" or "E".

The initial filtering phase was carried out including articles that met the inclusion criteria from their titles. Articles in which the title left some doubt were initially included. The second screening stage was performed through the reading of the abstracts. In this phase, only articles that fulfilled the adopted criteria remained. Finally, the articles that remained were read in full and organized. In this final phase some articles were excluded on the basis of the additional exclusion criteria. All procedures were adopted based on the flowchart developed by Preferred Reporting Items for Systematic Reviews and Meta-Analyses (PRISMA; Liberati et al., 2009).

\section{Results}

The systematic search returned a total of 357 publications from the three databases ad- able through the CAPES/MEC Journals Portal system or through the Western Libraries search system (Western University, Ontario, Canada). Additional exclusion criteria were also adopted considering the content presented: articles with unclear methodology (i.e., that did not adequately define or characterize the instrument used); studies in which the method of quantification was not clear such as the use of subjective criteria to generate quantitative data; review articles (bibliographic reviews, systematic reviews, meta-analyses, etc.) even when published through the peer review process; and instruments consisting of only one question or without psychometric data. 
tematic review were: 154 articles from the $W e b$ of Knowledge, Scopus and SciELO databases.
Figure 1 presents the flowchart suggested by the PRISMA initiative.

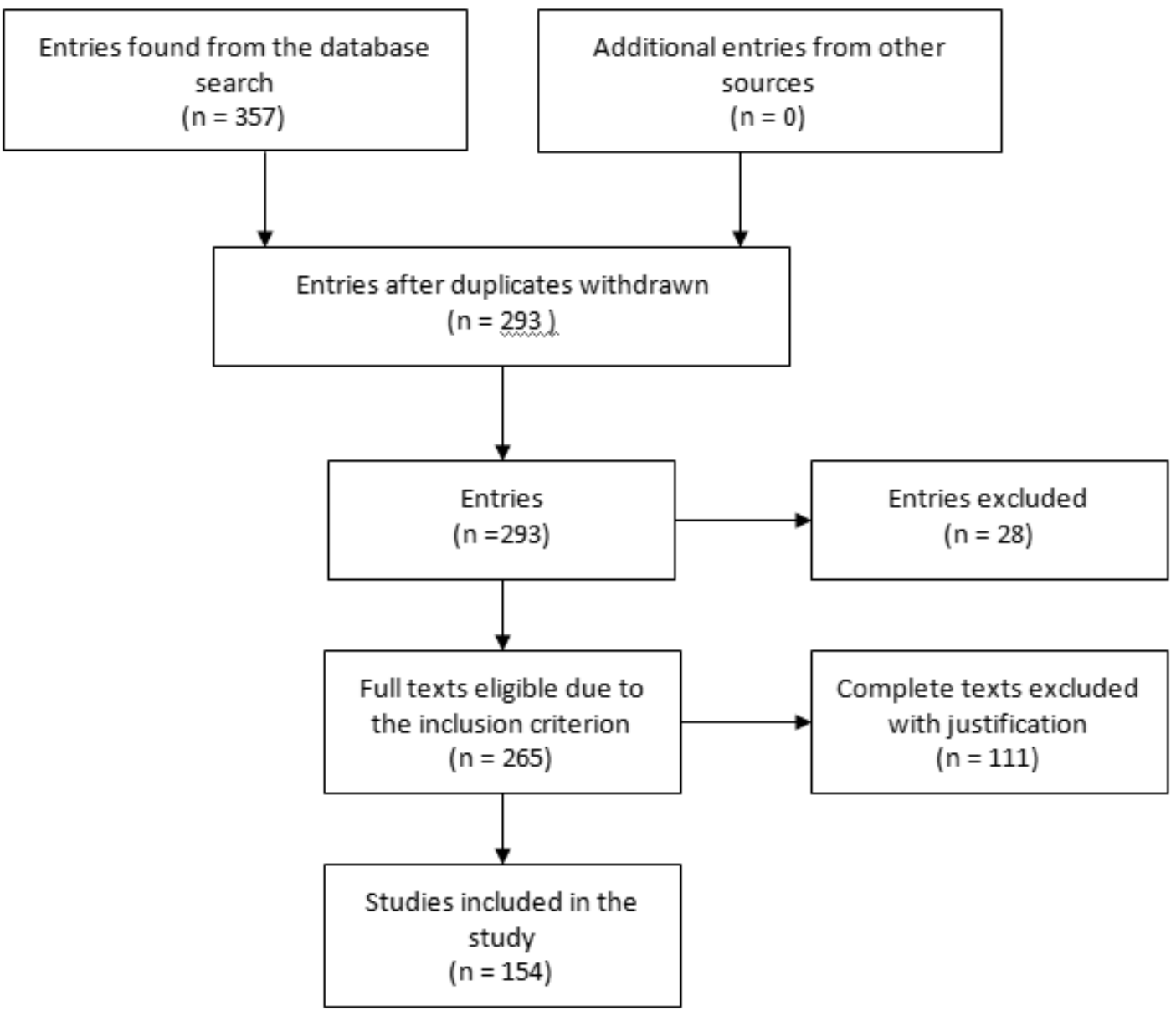

Figure 1. Complete flowchart of the articles

Source: Flowchart adapted from Liberati et al. (2009) and research data.

The complete results are in the supplementary material of this article. They include: the surnames of the authors, year of publication, country of origin of the study, instrument used, sample size and the nature or type of sample participants. The data highlight a wide variety of measures, with the 154 articles included in this review presenting 62 different scales used in 42 different countries. Table 2 shows the representation of the countries in the study.

In terms of the representation of the countries in the study, the United States appears as the country with more studies in the area of job satisfaction, accounting for $14.6 \%$ of all articles collected in the databases used. Brazil was in second place with $10.8 \%$, followed by Chile (9.6\%), Turkey (6.4\%), England (5.1\%), Co- lombia (4.5\%), China (3.8\%), Mexico (3.2\%), Canada, Spain and Poland (all with 2.5\%), these being the top ten in job satisfaction studies.

Considering the scales, the central focus of this work, the initial finding was the wide variability of instruments. Table 3 shows the number of publications, percentage of the representation of the instruments in the studies found in the present review, total sample of individuals that have responded to the scale, and whether or not there is a Brazilian version of the measure published in a peer review system journal.

Among the most used scales found in the databases, the most used and with the largest sample number was the Job Satisfaction Survey (JSS; Spector, 1985), followed by the Minnesota Job Satisfaction Questionnaire (MSQ; Weiss, 
Table 2

Search Results: Country of Study, Number of Publications (\# publications) for Each Country, Country Representation in the Results as Percentage (study \%) and Sum of Cumulative Percentages (cumulative \%)

\begin{tabular}{|c|c|c|c|c|c|c|c|}
\hline $\begin{array}{c}\text { Country of } \\
\text { study }\end{array}$ & $\begin{array}{c}\# \\
\text { publications }\end{array}$ & $\begin{array}{l}\text { Study } \\
\%\end{array}$ & $\begin{array}{c}\text { Cumulative } \\
\%\end{array}$ & $\begin{array}{l}\text { Country } \\
\text { of study }\end{array}$ & $\begin{array}{c}\# \\
\text { publications }\end{array}$ & $\begin{array}{l}\text { Study } \\
\%\end{array}$ & $\begin{array}{c}\text { Cumulative } \\
\%\end{array}$ \\
\hline USA & 23 & $14.6 \%$ & $14.6 \%$ & Finland & 2 & $1.3 \%$ & $84.6 \%$ \\
\hline Brazil & 17 & $10.8 \%$ & $25.4 \%$ & Netherlands & 2 & $1.3 \%$ & $85.9 \%$ \\
\hline Chile & 15 & $9.6 \%$ & $35.0 \%$ & Pakistan & 2 & $1.3 \%$ & $87.2 \%$ \\
\hline Turkey & 10 & $6.4 \%$ & $41.4 \%$ & Sweden & 2 & $1.3 \%$ & $88.5 \%$ \\
\hline England & 8 & $5.1 \%$ & $46.5 \%$ & Switzerland & 2 & $1.3 \%$ & $89.8 \%$ \\
\hline Colombia & 7 & $4.5 \%$ & $51.0 \%$ & Venezuela & 2 & $1.3 \%$ & $91.1 \%$ \\
\hline China & 6 & $3.8 \%$ & $54.8 \%$ & South Africa & 1 & $0.6 \%$ & $91.7 \%$ \\
\hline Mexico & 5 & $3.2 \%$ & $58.0 \%$ & Germany & 1 & $0.6 \%$ & $92.3 \%$ \\
\hline Canada & 4 & $2.5 \%$ & $60.5 \%$ & Croatia & 1 & $0.6 \%$ & $92.9 \%$ \\
\hline Spain & 4 & $2.5 \%$ & $63.0 \%$ & Egypt & 1 & $0.6 \%$ & $93.5 \%$ \\
\hline Poland & 4 & $2.5 \%$ & $65.5 \%$ & Ethiopia & 1 & $0.6 \%$ & $94.1 \%$ \\
\hline Australia & 3 & $1.9 \%$ & $67.4 \%$ & Iran & 1 & $0.6 \%$ & $94.7 \%$ \\
\hline South Korea & 3 & $1.9 \%$ & $69.3 \%$ & Israel & 1 & $0.6 \%$ & $95.3 \%$ \\
\hline Greece & 3 & $1.9 \%$ & $71.2 \%$ & Jordan & 1 & $0.6 \%$ & $95.9 \%$ \\
\hline Japan & 3 & $1.9 \%$ & $73.1 \%$ & Lebanon & 1 & $0.6 \%$ & $96.5 \%$ \\
\hline Norway & 3 & $1.9 \%$ & $75.0 \%$ & New Zealand & 1 & $0.6 \%$ & $97.1 \%$ \\
\hline Peru & 3 & $1.9 \%$ & $76.9 \%$ & Palestine & 1 & $0.6 \%$ & $97.7 \%$ \\
\hline Taiwan & 3 & $1.9 \%$ & $78.8 \%$ & Kenya & 1 & $0.6 \%$ & $98.3 \%$ \\
\hline $\begin{array}{c}\text { European } \\
\text { Union }\end{array}$ & 3 & $1.9 \%$ & $80.7 \%$ & Tanzania & 1 & $0.6 \%$ & $98.9 \%$ \\
\hline Argentina & 2 & $1.3 \%$ & $82.0 \%$ & Uganda & 1 & $0.6 \%$ & $99.5 \%$ \\
\hline Slovenia & 2 & $1.3 \%$ & $83.3 \%$ & Saudi Arabia & 1 & $0.6 \%$ & $100.0 \%$ \\
\hline
\end{tabular}

Dawis, \& England, 1967), the Questionário de satisfação laboral S20/23 (Meliá \& Peiró, 1989), the Cuestionario Font Roja de Satisfacción Laboral (Aranaz \& Mira, 1988), the Index of Work Satisfaction (IWS; Stamps, Piedmont, Slavitt, \& Haase, 1978), the Job Diagnostic Survey (JDS; Hackman \& Oldham, 1975), the Questionário Geral de Satisfação WCW (Warr et al., 1979), the McCloskey-Mueller Job Satisfaction Scale (MMSS; Mueller \& McCloskey, 1990) and the Escala de Satisfação no Trabalho (EST; Siqueira, 1995), with these instruments having at least 4 quantitative studies returned by the systematic review. Table 4 presents data of the most used scales in the studies found by this study, showing: instrument name, author of the original measure, instrument publication year, country of origin and countries with published studies using this measure.

Among the instruments most used in the studies returned by the systematic review, the MSQ (Weiss et al., 1967) had the largest number of different countries with studies using this measure, with a total of 11 countries. The MSQ was followed by the JSS (Spector, 1985), which had publications in 10 countries. Neither of the two scales, the JSS or MSQ, has a published Brazilian version. There were two scales with 
Table 3

Name of Instrument, Number of Publications (\# publications), Representation of the Scale in the Study (study \%), Sum of the Samples of the Publications (total sample) and Whether or Not there is a Brazilian Version of the Instrument Published through the Peer Review System

\begin{tabular}{|c|c|c|c|c|}
\hline Instrument & $\begin{array}{c}\# \\
\text { publications }\end{array}$ & $\begin{array}{l}\text { Study } \\
\%\end{array}$ & $\begin{array}{c}\text { Total } \\
\text { sample }\end{array}$ & $\begin{array}{l}\text { Brazilian } \\
\text { version }\end{array}$ \\
\hline Job Satisfaction Survey (JSS) & 17 & $11.0 \%$ & 11277 & No \\
\hline Minnesota Job Satisfaction Questionnaire (MSQ) & 15 & $9.7 \%$ & 4599 & No \\
\hline Cuestionario de satisfacción laboral S20/23 & 10 & $6.5 \%$ & 2460 & Yes \\
\hline Cuestionario Font Roja de Satisfacción laboral & 8 & $5.2 \%$ & 2634 & No \\
\hline Index of Work Satisfaction (IWS) & 8 & $5.2 \%$ & 2422 & No \\
\hline Job Diagnostic Survey (JDS) & 7 & $4.5 \%$ & 1827 & Yes \\
\hline Cuestionario WCW de escala general de satisfacción & 5 & $3.2 \%$ & 1161 & Yes \\
\hline McCloskey-Mueller Job Satisfaction Scale (MMSS) & 4 & $2.6 \%$ & 9867 & No \\
\hline Escala de Satisfação no Trabalho (EST) & 4 & $2.6 \%$ & 1471 & Yes \\
\hline Occupational Stress Indicator (OSI) & 3 & $1.9 \%$ & 9676 & Yes \\
\hline Teachers' job satisfaction questionnaire & 3 & $1.9 \%$ & 3028 & No \\
\hline Leiden Quality of Work Life Questionnaire (LQWQ) & 3 & $1.9 \%$ & 1547 & No \\
\hline Global Job Satisfaction (GJS) & 3 & $1.9 \%$ & 1178 & No \\
\hline Escala General de Satisfacción (Overall Job Satisfacción) & 3 & $1.9 \%$ & 394 & No \\
\hline $\begin{array}{l}\text { Escala de Satisfação no Trabalho do Occupational Stress } \\
\text { Indicator-OSI }\end{array}$ & 3 & $1.9 \%$ & 284 & Yes \\
\hline Job Descriptive Index (JDI) & 3 & $1.9 \%$ & 207 & No \\
\hline Home Healthcare Nurses' Job Satisfaction Scale (HHNJS) & 2 & $1.3 \%$ & 2614 & No \\
\hline $\begin{array}{l}\text { Cuestionario de satisfacción laboral de Chiang \& Nuñez } \\
\text { (2007) }\end{array}$ & 2 & $1.3 \%$ & 1481 & No \\
\hline $\begin{array}{l}\text { Kuopio University Hospital Job Satisfaction Scale } \\
\text { (KUHJSS) }\end{array}$ & 2 & $1.3 \%$ & 1424 & No \\
\hline Indice de Descripción del Trabajo (IDT) & 2 & $1.3 \%$ & 501 & No \\
\hline Job Satisfaction Inventory (JSI) & 2 & $1.3 \%$ & 413 & No \\
\hline Job Satisfaction Scale & 2 & $1.3 \%$ & 388 & No \\
\hline Employee Satisfaction Inventory (ESI) & 2 & $1.3 \%$ & 262 & No \\
\hline Job Satisfaction Questionnaire (JSQ-40) & 2 & $1.3 \%$ & 259 & No \\
\hline Job Description Inventory & 2 & $1.3 \%$ & 224 & No \\
\hline Índice de Satisfação no Trabalho (ISP) & 2 & $1.3 \%$ & 67 & Yes \\
\hline Early career job satisfaction instrument & 1 & $0.6 \%$ & 5865 & No \\
\hline Physician Worklife Survey (PWS) & 1 & $0.6 \%$ & 2325 & No \\
\hline Job Satisfaction Index Scale (JSIS) & 1 & $0.6 \%$ & 2080 & No \\
\hline $\begin{array}{l}\text { Escala de satisfacción laboral a partir de factores sociocul- } \\
\text { turales y ergoambientales (ESL-FSCyFEA) }\end{array}$ & 1 & $0.6 \%$ & 1837 & No \\
\hline
\end{tabular}


The Quality Work Competence (QWC)

$0.6 \% \quad 1633 \quad$ No

Ministerial Job Satisfaction Scale (MJSS)

$0.6 \% \quad 1276$

Measure of Job Satisfaction (MJS)

$0.6 \%$

983

No

Arabic satisfaction and commitment questionnaire (ASCQ)

$0.6 \%$

922

No

Escala General de Satisfacción Laboral (EGSL)

$0.6 \%$

731

No

Job Satisfaction Questionnaire by Ramirez (1996)

$0.6 \%$

681

No

Work Satisfaction Scale (WSS)

$0.6 \%$

No

Cuestionario de Satisfacción Laboral S21/27

$0.6 \%$

No

Assessment Scale of Team Satisfaction in Mental Health

Services (SATIS-BR)

$0.6 \%$

546

No

Overall Job Satisfaction Scale

Pennsylvania Registered Nurse Survey (PRNS)

$0.6 \%$

521

No

Nursing Home Certified Nurse Assistant Job Satisfaction questionnaire (NH-CNA-JS)

Work-Life Satisfaction Questionnaire (WLSQ)

Cuestionario de mejora de la satisfacción laboral (CMSL)

Spanish Quality of Professional Life Questionnaire (CPV-35)

$0.6 \%$

496

No

No

Work Satisfaction Questionnaire (WSQ)

$0.6 \% \quad 479$

No

Escala Satisfacción en la Relaciones Interpersonal en el

Trabajo (SRIT)

Job Content Questionnaire (JCQ-37)

Job Satisfaction Questionnaire by Warr, Cook, \& Wall (1979)

$0.6 \%$

450

No

Work Description Inventory (WDI)

$0.6 \%$

414

No

$0.6 \%$

404

No

$0.6 \%$

350

No

Japan Hospital Physicians Satisfaction Scale

$0.6 \%$

321

No

Cuestionario de Satisfacción Laboral S21/26

$0.6 \% \quad 300$

No

Escala de motivación laboral

Escala de Satisfacción Laboral (WES-10)

Index of Organisational Reactions

Index of Job Satisfaction

$0.6 \% \quad 275$

No

$0.6 \% \quad 240$

No

No

No

No

No

No

Escala de Avaliação da Satisfação de Profissionais em Serviços de Saúde Mental (SATIS-BR)

Job in General scale (JGI)

Satisfaction in Nursing Scale' (SINS)

Work Satisfaction Assessment Questionnaire (WSAQ)

Korean Music Therapists’ Job Satisfaction Scale (KMTJS)

Nursing Work Index-Revised (NWI-R)

$0.6 \%$

233

218

217

195

182

No

$0.6 \%$

172

Yes

$0.6 \%$

130

No

$0.6 \%$

113

No

1

$0.6 \%$

91

No

1

$0.6 \%$

90

No

1

$0.6 \%$

15

No

Note. The Job Diagnostic Survey (JDS) scale has a Brazilian version in a scientific journal that adopts the peer review system, however, does not have indexing in the databases used in the present study, therefore this is not included in the results. Bold: Scales with Brazilian versions. 
Table 4

Name of the Instrument, Author of the Original Measure, Year of Publication of the Instrument, Country of Origin and Countries with Studies Published Using the Instrument

\begin{tabular}{|c|c|c|c|c|}
\hline Instrument & Author & Year & Country of origin & Published Countries \\
\hline $\begin{array}{l}\text { Job Satisfaction Survey } \\
\text { (JSS) }\end{array}$ & Paul Spector & 1985 & USA & $\begin{array}{c}\text { Saudi Arabia } \\
\text { China } \\
\text { South Korea } \\
\text { Croatia } \\
\text { Egypt } \\
\text { USA } \\
\text { England } \\
\text { Norway } \\
\text { Turkey } \\
\text { European Union }\end{array}$ \\
\hline $\begin{array}{c}\text { Minnesota Job } \\
\text { Satisfaction } \\
\text { Questionnaire (MSQ) }\end{array}$ & $\begin{array}{c}\text { David Weiss, } \\
\text { Rene Dawis } \\
\& \text { George England }\end{array}$ & 1967 & USA & $\begin{array}{c}\text { South Africa } \\
\text { Australia } \\
\text { Chile } \\
\text { China } \\
\text { USA } \\
\text { England } \\
\text { Jordan } \\
\text { Pakistan } \\
\text { Peru } \\
\text { Taiwan } \\
\text { Turkey }\end{array}$ \\
\hline $\begin{array}{c}\text { Cuestionario } \\
\text { de satisfacción laboral } \\
\text { S20/23 }\end{array}$ & $\begin{array}{l}\text { José Meliá } \\
\text { \& José Peiró }\end{array}$ & 1989 & Spain & $\begin{array}{l}\text { Argentina } \\
\text { Brazil } \\
\text { Chile } \\
\text { Colombia }\end{array}$ \\
\hline $\begin{array}{c}\text { Cuestionario } \\
\text { Font Roja de } \\
\text { Satisfacción laboral }\end{array}$ & $\begin{array}{c}\text { Jesus Aranaz } \\
\text { \& José Joaquín Mira }\end{array}$ & 1988 & Spain & $\begin{array}{l}\text { Chile } \\
\text { Colombia } \\
\text { Spain } \\
\text { Mexico }\end{array}$ \\
\hline $\begin{array}{c}\text { Index of Work } \\
\text { Satisfaction (IWS) }\end{array}$ & $\begin{array}{l}\text { Paula Stamps, } \\
\text { Eugene Piedmont, } \\
\text { Dinah Slavitt } \\
\text { \& Ann Haase }\end{array}$ & 1978 & USA & $\begin{array}{l}\text { USA } \\
\text { Finland } \\
\text { Greece } \\
\text { Japan } \\
\text { Norway }\end{array}$ \\
\hline $\begin{array}{l}\text { Job Diagnostic Survey } \\
\text { (JDS) }\end{array}$ & $\begin{array}{l}\text { J. Richard Hackman } \\
\text { \& Greg Oldman }\end{array}$ & 1975 & USA & $\begin{array}{c}\text { Slovenia } \\
\text { USA } \\
\text { England } \\
\text { New Zealand } \\
\text { Switzerland }\end{array}$ \\
\hline $\begin{array}{l}\text { WCW Job satisfaction } \\
\text { scale (WCW) }\end{array}$ & $\begin{array}{l}\text { Peter Warr, } \\
\text { John Cook, } \\
\text { \& Toby Wall }\end{array}$ & 1979 & USA & $\begin{array}{l}\text { Germany } \\
\text { Chile } \\
\text { Peru } \\
\text { Venezuela }\end{array}$ \\
\hline $\begin{array}{c}\text { McCloskey-Mueller } \\
\text { Job Satisfaction Scale } \\
\text { (MMSS) }\end{array}$ & $\begin{array}{l}\text { Charles Mueller \& } \\
\text { Joanne McCloskey }\end{array}$ & 1990 & USA & $\begin{array}{c}\text { Canada } \\
\text { Slovenia } \\
\text { USA } \\
\text { Palestine }\end{array}$ \\
\hline $\begin{array}{c}\text { Escala de Satisfação } \\
\text { no Trabalho (EST) }\end{array}$ & $\begin{array}{c}\text { Mirlene Maria Matias } \\
\text { Siqueira }\end{array}$ & 1995 & Brazil & Brazil \\
\hline
\end{tabular}


5 countries each, these being: the IWS (Stamps et al., 1978) and the JDS (Hackman \& Oldham, 1975), however, only the JDS had a study in Brazil (Pedroso et al., 2014) published in a peer review system, although without SciELO, Web of Knowledge or Scopus indexing.

Regarding the place of origin of the instruments, 6 of the 9 main ones were originally published and developed in the United States, however, two questionnaires, namely the S20/23 (Meliá \& Peiró, 1989) and the Font Roja (Aranaz \& Mira, 1988), were developed in Spain and have been used extensively in Latin American countries such as Argentina, Brazil, Chile, Colombia and Mexico. Only one of the scales most used in the articles returned by the review was created in Brazil: the Escala de Satisfação no Trabalho of Siqueira (1995). As this is a Brazilian questionnaire there were only Brazilian studies that used it; this phenomenon will be discussed later.

\section{Discussion}

The present work aimed to identify the state of the art in measuring instruments for the investigation of job satisfaction in PW\&O studies. In this sense, the systematic review used the PRISMA procedure (Liberati et al., 2009) with three databases: SciELO, Web of Knowledge and Scopus. It should be emphasized that the SciELO database mainly contains studies performed in Latin America, the Caribbean and Brazil, which probably caused a distortion in the results, with greater concentration in this region, without this reflecting the worldwide representation. Strong evidence for this assertion comes from the Brazilian studies in that, of the 17 articles returned after the search procedure in the databases, only 2 were published in journals indexed in the $W e b$ of Knowledge and none in Scopus; therefore, 15 articles came from the SciELO database, only having visibility within Latin America and not in other regions.

The importance of using instruments that are also studied in other countries of the world primarily comes from the ability to reproduce the results. An important recent study presented reproducibility data (ability of a theory to be confirmed and results reproduced in different cultural and experimental contexts) in the areas of Social and Cognitive Psychology (Van Bavel et al., 2016). The article indicated that Cognitive Psychology can reproduce its results in $53 \%$ of the cases, which is little in scientific terms, however, significant in probabilistic terms, as it is higher than the level of chance. On the other hand, studies in Social Psychology tend to have indexes of reproducibility close to $25 \%$, which represents 1 in 4 studies confirming a theory. Van Bavel et al. (2016) argued that the failure of the reproduction of quantitative results in Social Psychology is due to cultural contexts and the heterogeneity of the instruments used in these studies. The point is that this problem testifies against psychological science, given the level of uncertainty greater than the level of certainty.

The cultural distinction in Social Psychology is a dimension that should be considered at the time of the studies in diverse countries. The ITC is a multinational body that aims to establish guidelines for quantitative studies using psychological tests. One of these guidelines concerns the adaptations of instruments for different countries. Using the same measure and the same method are important for testing theoretical models, however, there is no way to think of using a scale developed in the United States without any adaptation for Brazil, due to linguistic and cultural issues. Therefore, the ITC (2010) established clear criteria for the crosscultural adaptation of tests. The care emphasized by Van Bavel et al. (2016) in seeking to use the same measures combined with the adaptation of the instrument to the social context in which it will be used (ITC, 2010) seem to contribute to reduce the problem of contemporary Social Psychology. It is in this sense that the present article seeks to make its contribution, presenting the gap that these results demonstrate: the lack of instruments adapted to the Brazilian culture that are used in diverse countries of the world to promote the testing of current theories. 
Considering these issues, the present study discusses measures at three levels: the world, Latin America and Brazil. The results suggest that the most used instruments worldwide are the JSS, with 17 (11.0\%), and the MSQ with 15 (9.7\%) of the quantitative studies returned by the three databases searched. In this sense, practically 1 in every 5 articles use one of these two instruments in more than 17 of the 42 countries indicated (a ratio of practically 1 in 3 ). Even considering the skewness due to the presence of the SciELO database, these two scales can be considered central to studies of job satisfaction and, interestingly, the Brazilian published versions of these instruments were not found in the present study, which shows a gap in satisfaction studies in Brazil.

From the perspective of Latin America, the Font Roja and S20/23 questionnaires were the most returned with 8 and 10 articles respectively. In the Latin American scenario, a Brazilian version of the most used questionnaire, the S20/23, was found in the search (Carlotto \& Câmara, 2008). However, the Font Roja does not have a Brazilian version, which leaves Brazil behind its Latin American and Iberian peers, since the instrument was developed and has been used consistently in Spain (Aranaz \& Mira, 1988). The hypothesis of this study is that the language barrier is an impediment for Brazilian instruments to be adopted by the other Latin American countries and accordingly no Brazilian questionnaire adapted for Spanish or Castilian was found by the search of this study. Therefore, at the national level, the instrument most widely used in the Brazilian literature, the Escala de Satisfação no Trabalho (EST; Siqueira, 1995), has only been used in Brazil. The quality of the scale is demonstrated by the solidity of its use in the country, however, this restricted use hampers reproducibility and respect for theoretical views in satisfaction studies (Van Bavel et al., 2016), respecting the cross-cultural idiosyncrasies (ITC, 2010). The following is a survey of the most used instruments in these scenarios: worldwide (JSS and MSQ), Latin American (S20/23 and Font Roja) and Brazilian (EST).

\section{Job Satisfaction Survey}

Among the results found, the instrument most commonly used worldwide in numerical terms was the JSS (Spector, 1985, 1997). Developed by Paul Spector in 1985, the JSS is a 36item scale that provides an evaluation through a Likert-type scale of 6 categories (i.e., 1-disagree very much, 2-disagree moderately, 3-disagree slightly, 4-agree slightly, 5-agree moderately, and 6-agree very much) of agreement in relation to nine dimensions of job satisfaction: (1) nature of the work, (2) remuneration, (3) promotion, (4) supervisors, (5) co-workers, (6) benefits, (7) contingency rewards, (8) operational procedures and (9) quality of the communication.

The theoretical framework from which the JSS is constituted is the Range of Affect Theory (Locke, 1976, 1991; Locke \& Latham, 2002), the most widely used approach among the theories that explain job satisfaction according to literature surveys conducted at different moments (Spector, 1997; van Saane et al., 2003). This framework comes from satisfaction with an attitude based on the positive and negative affects in relation to the job. In this approach, job satisfaction is determined by the difference between positive and negative affects.

The JSS was found to have been used in 10 countries, according to the results, and the sample of the 17 studies included 11,000 participants, which indicates the strength of the measure in international terms. In fact, the JSS has been extensively studied and has allowed the development of a theoretical model that explains satisfaction, motivation and performance in the work environment (Locke \& Latham, 2002). The JSS option seems most appropriate for researchers seeking robustness and ease of replication of large samples

\section{Minnesota Satisfaction Questionnaire}

In the results, the MSQ (Weiss et al., 1967) represented the second position in terms of number of studies, with 15 published articles using the scale. Internationally, the MSQ is a good choice for the researcher, since it is the instru- 
ment that has been used in the greatest number of countries according to the results, totaling 11 places; one more than the JSS. It seems, however, that regarding the sample size, the MSQ researchers tend to use fewer participants, since the inclusion of 4,599 participants places it in only fifth place.

The MSQ was developed in 1967 by three researchers based on the theoretical framework of attitude. The questionnaire considers satisfaction as an attitude with positive and negative affects, as suggested by Locke (1976), divided into 20 facets. The scale consists of 100 items in the full version and 20 items in its reduced version, which evaluate the 20 facets of satisfaction (Spector, 1997): (1) activity, (2) independence, (3) variety, (4) social status, (5) supervision (human relations), (6) supervision (technical), (7) moral values, (8) security, (9) authority, (10) use of skills, (11) corporate policies and practices, (12) remuneration, (13) advancement, (14) responsibility, (15) creativity, (16) working conditions, (17) work colleagues, (18) social service, (19) recognition and (20) achievements. The answers vary according to a Likert-type scale of 5 categories according to the level of satisfaction with each facet of the work, going from 1-very dissatisfied to 5-very satisfied.

\section{Questionário de Satisfação no Trabalho S20/23}

The S20/23 questionnaire is a reduced version of the S4/82 original scale (Carlotto \& Câmara, 2008; Meliá \& Peiró, 1989). In this format, the measure has 23 items divided into 5 factors: (1) Satisfaction with supervision, (2) Satisfaction with the physical work environment, (3) Satisfaction with benefits and policies of the organization, (4) Intrinsic job satisfaction and (5) Satisfaction with participation. The answers are given on a Likert-type satisfaction scale ranging from 1-very dissatisfied (muy insatisfecho in Spanish) to 7-very satisfied (muy satisfecho in Spanish).

According to Meliá and Peiró (1989), the S20/23 and its original version the S4/82 were constructed from reviews of the empirical literature that used factor analysis methods to determine the number of job satisfaction dimensions. This means that there is not exactly a single theoretical basis, but the creation of a measure with an empirical bias (Carlotto \& Câmara, 2008).

In the Latin American context, the S20/23 was the most used instrument, with 10 studies using it. The results show that the scale was used in studies from 4 countries: Brazil, Argentina, Chile and Colombia, which shows its broad character and good adherence in the South American countries. This makes it a measure that facilitates the promotion of studies with international collaboration, mainly among South American nations.

\section{Cuestionario Font Roja de Satisfacción Laboral}

The Font Roja questionnaire on job satisfaction was originally developed in Spain to assess the satisfaction of nurses and health professionals in the hospital environment (Aranaz \& Mira, 1988). This orientation was based on the demand for instruments that were adapted to the reality of the hospital worker that suffers from wear and multiple demands that go beyond the corporate and public context in general (Núñez González, Estévez Guerra, Hernández Marrero, \& Marrero Medina, 2007). This measure has a 9 factor structure: (1) job satisfaction; (2) job stress; (3) professional competence; (4) job pressure; (5) professional promotion; (6) interpersonal relationships with superiors; (7) interpersonal relationships with co-workers; (8) extrinsic characteristics of social status; (9) job monotony. Its dimensions are divided into 24 response items that measure the satisfaction level through a Likert-type scale ranging from 1-very dissatisfied (muy insatisfecho in Spanish) to 5-very satisfied (muy satisfecho in Spanish).

Recently, Núñez González et al. (2007) developed 2 other items for the scale in order to evaluate a new dimension that considers the physical work space. This addition created an extended version of the measure with 10 factors and 26 items. In the Latin American panorama, the instrument was used in 7 articles, with 3 being from Mexico, 1 from Chile and 3 from Co- 
lombia. Considering Iberia, Spain $(n=1)$ also produced a study with the instrument, due to its origin and specificity. In this context, it is worth remembering that it is a measure constructed for the hospital context and, therefore, its relevance for this environment justifies its use in samples with this common characteristic. From this condition, Latin American researchers can take advantage of this instrument to measure satisfaction in the work of nurses and health professionals.

\section{Escala de Satisfação no Trabalho}

The only scale developed in Brazil and returned in the databases used was the EST (Siqueira, 1995, 2003). Developed by Mirlene Maria Siqueira in 1995 for her doctoral thesis, the instrument is based on the theoretical model developed by the researcher called the "Post-cognitive model for behaviors of organizational citizenship" (Modelo pós-cognitivo para comportamentos de cidadania organizacional; Siqueira, 2003, p. 168). This theoretical approach presupposes that cognitions (which the author characterizes as: perception of organizational reciprocity, perception of organizational support and calculative organizational commitment) will develop affects of the worker towards the company (divided into job satisfaction, involvement with the work and affective organizational commitment) that will result in actions of organizational citizenship. In this sense, satisfaction is seen as an element of affection which, in turn, is generated from thoughts based on the values and beliefs of the worker in relation to the world of work. To be satisfied, therefore, would be to be committed to an organization that has values and beliefs congruent with those of the worker (Siqueira, 1995, 2003). The notion of the affect as a fruit of the beliefs and values places cognition at the center of the attitude, which runs counter to the notion of attitude as affect adopted by Locke (1976) and used by most researchers in the area (Fritzsche \& Parrish, 2004; Judge \& Bono, 2001; Latham \& Budworth, 2007; Locke, 1991; Locke \& Latham, 2002; Spector, 1997; Stamps et al., 1978; Warr et al., 1979; Weiss et al., 1967)
Despite the distinct theoretical model, the EST has studies demonstrating evidence of validity and good statistical properties (Siqueira, 1995). The measure has 25 items divided into 5 factors: (1) satisfaction with colleagues, (2) satisfaction with salary, (3) satisfaction with management, (4) satisfaction with the nature of the work and (5) satisfaction with promotions. The answers are given on a Likert-type scale of 7 levels of agreement.

Regarding the use of the EST, 4 articles were found that used the instrument to study job satisfaction, however, all were published in Brazil and found in the SciELO database. Clearly there is a willingness of Brazilian researchers to use the measure and this is due to the fact that the EST was developed in the Brazilian context, facilitating its use. Another obstacle that is overcome by the EST is the linguistic dimension and the lack of need for cross-cultural adaptation (ITC, 2010). However, there were no international articles that used the EST, not even studies of adaptation to other countries, which can be explained from two untested hypotheses: (a) the instrument was constructed from a theoretical view little shared by researchers outside Brazil, or (b) the presence of versions of instruments more used to study job satisfaction already adapted to the reality of these countries makes it easy for the researcher, which discourages the use of the EST. Whatever the hypothesis, for the researcher who starts from the theoretical assumption that satisfaction is a consequence of the congruence between the worker's cognitions and what is offered by the company, the EST seems to be the most appropriate method of measurement, regardless of the country of origin of the study.

\section{Limitations and Conclusions}

The aim of this article was to search the literature with regard to the state of the art of measuring instruments in the area of job satisfaction in this second decade of the 21 st century. When the three levels of the study: the world, Latin America and Brazil, were applied five measures were highlighted. Worldwide, the JSS 
(Spector, 1985) and MSQ (Weiss et al., 1967) are the most comprehensive and most answered measures, however, it is still necessary that studies of cross-cultural adaptation and validation in Brazil be carried out and published to give robustness to the use of the measures and allow the replication of results considering the theoretical view of Locke (1976). In Latin America, the S20/23 (Meliá \& Peiró, 1989) and the Font Roja (Aranaz \& Mira, 1988) were the main scales used to allow international collaborations in this region. While the S20/23 has a Brazilian version and some empirical studies (Carlotto \& Câmara, 2008), the Font Roja, due to its specificity (nurses and health professionals), does not yet have an version adapted to Brazil. Specifically in the Brazilian context, the EST (Siqueira, 1995) is a scale developed from a theoretical perspective distinct from that of Locke (1976), however, equally important. In this sense, Brazil is privileged to be able to test the theoretical model of satisfaction as an attitude from the perspective of affect and cognition. However, it seems that there is no international willingness to adapt the EST, leaving it isolated in terms of the worldwide scenario of job satisfaction research.

This work identified many articles that used empirical and psychometric methods to measure job satisfaction, however, the multiplicity of measures, totaling 62 instruments, hinders conclusions in this field of research. Inclusion and exclusion criteria were very lenient, which is probably why 154 articles were generated for review. Although the theme of the article is simple, this number seems excessive. Another aspect that deserves special mention is that thesis and dissertation works do not appear in these databases, however, there are indications that some of these measures were adapted without this being common knowledge due to constituting unpublished material.

The aim of the study was fulfilled, however, the field of research in job satisfaction still lacks studies that adapt and investigate psychometric properties, mainly for the most used instruments that do not present published Brazilian version. It is hoped that in future studies researchers can reexamine these measurement methods.

\section{References}

Abbas, M., Raja, U., Darr, W., \& Bouckenooghe, D. (2014). Combined effects of perceived politics and psychological capital on job satisfaction, turnover intentions, and performance. Journal of Management, 40(7), 1813-1830. doi: http:// doi.org/10.1177/0149206312455243

Alarcon, G. M., \& Edwards, J. M. (2011). The relationship of engagement, job satisfaction and turnover intentions. Stress and Health, 27(3), e294-e298. doi: http://doi.org/10.1002/smi.1365

Aranaz, J., \& Mira, J. J. (1988). Cuestionario Font Roja. Un instrumento de medida de la satisfacción en el medio hospitalario. Todo Hospital, 52, 63-66.

Carlotto, M. S., \& Câmara, S. G. (2008). Propriedades psicométricas do Questionário de Satisfação no Trabalho (S20/23). Psico-USF, 13(2), 203-210. doi: http://doi.org/10.1590/S141382712008000200007

Chen, Z., Lam, W., \& Zhong, J. A. (2007). Leadermember exchange and member performance: A new look at individual-level negative feedbackseeking behavior and team-level empowerment climate. Journal of Applied Psychology, 92(1), 202-212. doi: http://doi.org/10.1037/00219010.92.1.202

Fritzsche, B., \& Parrish, T. (2004). Theories and Research in Job Satisfaction. In S. D. Brown \& R. W. Lent (Eds.), Career Development and Counseling: Putting Theory and Research to Work (pp. 180-201). New York: John Wiley \& Sons.

Hackman, J. R., \& Oldham, G. R. (1975). Development of the Job Diagnostic Survey. Journal of Applied Psychology, 60(2), 159-170. doi: http:// doi.org/10.1037/h0076546

International Test Comission. (2010). International Test Commission Guidelines for Translating and Adapting Tests. Retrieved from http://www. intestcom.org/upload/sitefiles/40.pdf

Judge, T. A., \& Bono, J. E. (2001). Relationship of core self-evaluations traits-self-esteem, generalized self-efficacy, locus of control, and emotional stability - with job satisfaction and job performance: A meta-analysis. Journal of Applied Psychology, 86(1), 80-92.

Latham, G. P., \& Budworth, M. H. (2007). The study of work motivation in the 20th century. 
In L. L. Koppes (Ed.), Historical perspectives in industrial and organizational psychology (pp. 353-381). Mahwah, NJ: Lawrence Erlbaum Associates.

Liberati, A., Altman, D. G., Tetzlaff, J., Mulrow, C., Gøtzsche, P. C., Ioannidis, J. P. A., ...Moher, D. (2009). The PRISMA Statement for Reporting Systematic Reviews and Meta-Analyses of Studies That Evaluate Health Care Interventions: Explanation and Elaboration. PLoS Medicine, 6(7), e1000100. doi: http://doi.org/10.1371/journal. pmed. 1000100

Locke, E. A. (1976). The nature and causes of job satisfaction. In M. D. Dunnette (Ed.), Handbook of industrial and organizational psychology (pp. 1297-1349). Chicago, IL: Rand McNally.

Locke, E. A. (1991). Goal theory vs. control theory: Contrasting approaches to understanding work motivation. Motivation and Emotion, 15(1), 9-28. doi: http://doi.org/10.1007/BF00991473

Locke, E. A., \& Latham, G. P. (2002). Building a practically useful theory of goal setting and task motivation: A 35-year odyssey. American Psychologist, 57(9), 705-717. doi: http://doi. org/10.1037//0003-066X.57.9.705

Mathieu, C., Fabi, B., Lacoursière, R., \& Raymond, L. (2016). The role of supervisory behavior, job satisfaction and organizational commitment on employee turnover. Journal of Management \& Organization, 22(1), 113-129. doi: http://doi. org/10.1017/jmo.2015.25

Meliá, J. L., \& Peiró, J. M. (1989). La medida de la satisfacción laboral en contextos organizacionales: el Cuestionario de Satisfacción S20/23. Psicologemas, 5, 59-74.

Mudor, H., \& Tooksoon, P. (2011). Conceptual framework on the relationship between human resource management practices, job satisfaction, and turnover. Journal of Economics and Behavioral Studies, 2(2), 41-49.

Mueller, C. W., \& McCloskey, J. C. (1990). Nurses' Job Satisfaction: A Proposed Measure. Nursing Research, 39(2), 113-117.

Núñez González, E., Estévez Guerra, G. J., Hernández Marrero, P., \& Marrero Medina, C. D. (2007). Una propuesta destinada a complementar el cuestionario Font-Roja de satisfacción laboral. Gaceta Sanitaria, 21(2), 136-141. doi: http://doi.org/10.1157/13101040
Nyberg, A. (2010). Retaining your high performers: Moderators of the performance-job satisfaction-voluntary turnover relationship. Journal of Applied Psychology, 95(3), 440-453. doi: http:// doi.org/10.1037/a0018869

Pedroso, B., Kovaleski, A., Ferreira, C. L., Pilatti, L. A., Gutierrez, G. L., \& Picinin, C. T. (2014). Desenvolvimento e validação da versão brasileira do Diagnóstico do Trabalho (Job Diagnostic Survey) de Hackman e Oldham. Gestão \& Produção, 21(2), 285-301. doi: http://doi. org/10.1590/0104-530X198

Singh, P., \& Loncar, N. (2010). Pay Satisfaction, Job Satisfaction and Turnover Intent. Relations Industrielles, 65(3), 470-490.

Siqueira, M. M. M. (1995). Antecedentes de comportamentos de cidadania organizacional: A análise de um modelo pós-cognitivo (Doctoral dissertation, Universidade de Brasília, DF, Brazil).

Siqueira, M. M. M. (2003). Proposição e análise de um modelo para comportamentos de cidadania organizacional. Revista de Administração Contemporânea [Special issue], 7, 165-184. doi: http:// doi.org/10.1590/S1415-65552003000500009

Spector, P. E. (1985). Measurement of human service staff satisfaction: Development of the Job Satisfaction Survey. American Journal of Community Psychology, 13(6), 693-713. doi: http://doi. org/10.1007/BF00929796

Spector, P. E. (1997). Job Satisfaction: Application, Assessment, Causes, and Consequences. Thousand Oaks, CA: Sage.

Stamps, P. L., Piedmont, E. B., Slavitt, D. B., \& Haase, A. M. (1978). Measurement of Work Satisfaction among Health Professionals. Medical Care, 16(4), 337-352.

Uhrbrock, R. S. (1934). Attitudes of 4430 Employees. The Journal of Social Psychology, 5(3), 365377. doi: http://doi.org/10.1080/00224545.193 4.9921604

Van Bavel, J. J., Mende-Siedlecki, P., Brady, W. J., \& Reinero, D. A. (2016). Reply to Inbar: Contextual sensitivity helps explain the reproducibility gap between social and cognitive psychology. Proceedings of the National Academy of Sciences, 113(34), E4935-E4936. doi: http:// doi.org/10.1073/pnas.1609700113 
Van De Voorde, K., Paauwe, J., \& Van Veldhoven, M. (2012). Employee Well-being and the HRMOrganizational Performance Relationship: A Review of Quantitative Studies. International Journal of Management Reviews, 14(4), 391-407. doi: http://doi.org/10.1111/j.14682370.2011.00322.x

Van Saane, N., Sluiter, J. K., Verbeek, J. H. A. M., \& Frings-Dresen, M. H. W. (2003). Reliability and validity of instruments measuring job satisfaction--A systematic review. Occupational Medicine, 53(3), 191-200. doi: http://doi.org/10.1093/ occmed/kqg038

Warr, P., Cook, J., \& Wall, T. (1979). Scales for the measurement of some work attitudes and aspects of psychological well-being. Journal of Occupational Psychology, 52(2), 129-148. doi: http:// doi.org/10.1111/j.2044-8325.1979.tb00448.x
Weiss, D., Dawis, R., \& England, G. (1967). Manual for the Minnesota Satisfaction Questionnaire. Minneapolis, MI: Minnesota Studies in Vocational Rehabilitation.

Yousef, D. A. (2017). Organizational Commitment, Job Satisfaction and Attitudes toward Organizational Change: A Study in the Local Government. International Journal of Public Administration, 40(1), 77-88. doi: http://doi.org/10.1080 /01900692.2015.1072217
Received: 02/02/2017

$1{ }^{\text {st }}$ revision: 07/06/2017

Accepted: 08/06/2017 